Utah State University

DigitalCommons@USU

Articles

Publications

2017

\title{
Developing a Parameterization Approach for Soil Erodibility for the Rangeland Hydrology and Erosion Model (RHEM)
}

\author{
Osama Z. Al-Hamdan \\ Texas A\&M University \\ Frederick B. Pierson \\ USDA, Agricultural Research Service \\ Mark A. Nearing \\ USDA, Agricultural Research Service \\ Christopher Jason Williams \\ USDA, Agricultural Research Service \\ Mariano Hernandez \\ USDA, Agricultural Research Service \\ Jan Boll \\ Washington State University
}

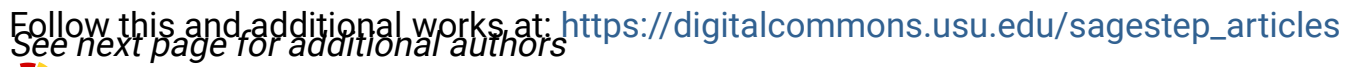

Part of the Plant Sciences Commons

\section{Recommended Citation}

Al-Hamdan, O.Z., F.B. Pierson, M.A. Nearing, C.J. Williams, M. Hernandez, J. Boll, S.K. Nouwakpo, M.A. Weltz and K.E. Spaeth. 2017. Developing a parameterization approach of soil erodibility for the Rangeland Hydrology and Erosion Model. Transactions of the ASABE. 60:85-94. DOI 10.13031/trans.11559

This Article is brought to you for free and open access by the Publications at DigitalCommons@USU. It has been accepted for inclusion in Articles by an authorized administrator of DigitalCommons@USU. For more information, please contact digitalcommons@usu.edu.

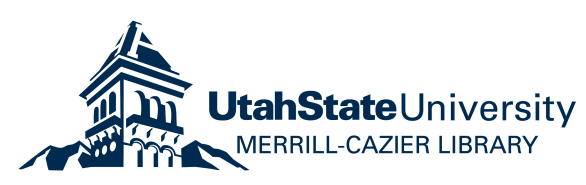




\section{Authors}

Osama Z. Al-Hamdan, Frederick B. Pierson, Mark A. Nearing, Christopher Jason Williams, Mariano Hernandez, Jan Boll, Sayjro K. Nouwakpo, Mark A. Weltz, and Kenneth Spaeth 


\title{
DEVELOPING A PARAMETERIZATION APPROACH FOR SOIL ERODIBILITY FOR THE RANGELAND HYDROLOGY AND EROSION MODEL (RHEM)
}

\author{
O. Z. Al-Hamdan, F. B. Pierson, M. A. Nearing, C. J. Williams, \\ M. Hernandez, J. Boll, S. K. Nouwakpo, M. A. Weltz, K. Spaeth
}

\begin{abstract}
Soil erodibility is a key factor for estimating soil erosion using physically based models. In this study, a new parameterization approach for estimating erodibility was developed for the Rangeland Hydrology and Erosion Model (RHEM). The approach uses empirical equations that were developed by applying piecewise regression analysis to predict the differences of erodibility before and after disturbance (i.e., wildfire, prescribed fire, and tree encroachment) and across a wide range of soil textures as a function of vegetation cover and surface slope angle. The approach combines rain splash, sheet flow, and concentrated flow erodibilities into a single parameter for modeling erodibility in most cases. We evaluated the new approach for sites representing different degrees of disturbance associated with burning and tree encroachment. Our results show that the new erodibility approach in RHEM predicts erosion at the plot scale with a satisfactory range of error in all cases. The new approach extends the applications of RHEM to a greater scope of landscapes and soil texture.
\end{abstract}

Keywords. Erodibility, Fire, RHEM, Rill, Segmented regression, Soil erosion modeling, Tree encroachment, WEPP.

$\mathrm{T}$ he Rangeland Hydrology and Erosion Model (RHEM) (Nearing et al., 2011; Al-Hamdan et al., 2015) is a process-based model that estimates runoff, erosion, and sediment delivery rates and volumes at the spatial scale of the hillslope and the temporal scale of a single rainfall event. RHEM model parameterization represents erosion processes on undisturbed rangelands as well as rangelands that exhibit some disturbance, such as fire or woody plant encroachment (Nearing et al., 2011; Hernandez et al., 2013; Al-Hamdan et al., 2015; Williams et al., 2016). In RHEM, soil detachment is predicted as a combination of two erosion processes: rain splash and thin sheet flow

Submitted for review in September 2015 as manuscript number NRES 11559; approved for publication by the Natural Resources \& Environmental Systems Community of ASABE in October 2016.

Mention of company or trade names is for description only and does not imply endorsement by the USDA. The USDA is an equal opportunity provider and employer.

The authors are Osama Z. Al-Hamdan, Assistant Professor, Department of Civil and Architectural Engineering, Texas A\&M University, Kingsville, Texas; Frederick B. Pierson, Research Leader, USDA-ARS Northwest Watershed Research Center, Boise, Idaho; Mark A. Nearing, Research Agricultural Engineer, C. Jason Williams, Research Hydrologist, and Mariano Hernandez, Hydrologist, USDA-ARS Southwest Watershed Research Center, Tucson, Arizona; Jan Boll, Professor, Department of Civil and Environmental Engineering, Washington State University, Pullman, Washington; Sayjro K. Nouwakpo, Research Assistant Professor, Department of Natural Resources and Environmental Sciences, University of Nevada, Reno, Nevada; Mark A. Weltz, Research Leader, USDA-ARS Great Basin Rangelands Research Unit, Reno, Nevada; Kenneth Spaeth, Rangeland Management Specialist, USDA-NRCS Central National Technology Support Center, Fort Worth, Texas. Corresponding author: Osama Z. AlHamdan, EC 356, MSC 194 Texas A\&M University, Kingsville, TX 78363 8202; phone: 361-593-4075; email: osama.al-hamdan@tamuk.edu. (splash and sheet) detachment, and concentrated flow detachment. Splash and sheet detachment is calculated by (Wei et al., 2009):

$$
D_{S S}=K_{S S}\left(I^{1.052} q^{0.592}\right)
$$

where

$D_{S S}=$ splash and sheet detachment rate $\left(\mathrm{kg} \mathrm{s}^{-1} \mathrm{~m}^{-2}\right)$

$K_{S S}=$ splash and sheet erodibility

$I=$ rainfall intensity $\left(\mathrm{m} \mathrm{s}^{-1}\right)$

$q=$ discharge per unit width $\left(\mathrm{m}^{2} \mathrm{~s}^{-1}\right)$.

Concentrated flow detachment is a function of concentrated flow detachment capacity $\left(D_{c}, \mathrm{~kg} \mathrm{~s}^{-1} \mathrm{~m}^{-2}\right)$, which is calculated by (Al-Hamdan et al., 2012a):

$$
D_{c}=K_{\omega}(\omega)
$$

where

$K_{\omega}=$ concentrated flow erodibility $\left(\mathrm{s}^{2} \mathrm{~m}^{-2}\right)$

$\omega=$ stream power (hydraulic parameter) $\left(\mathrm{kg} \mathrm{s}^{-3}\right)$.

Hence, in order to estimate the total soil sediment yield,

RHEM requires two erodibility factors: $K_{S S}$ and $K_{\omega}$.

The current erodibility parameterization in RHEM is based on rainfall simulation data representing undisturbed and disturbed rangelands. Nearing et al. (2011) used rainfall simulation data ( $3.06 \mathrm{~m}$ wide by $10.7 \mathrm{~m}$ long plots) collected as part of the Water Erosion Prediction Project (WEPP) Rangeland Field Experiment (Simanton et al., 1991; Laflen et al., 1991) and by the Interagency Rangeland Water Erosion (IRWET) and National Range Study Teams (NRST) (Franks et al., 1998) to develop estimation equations of splash and sheet erodibility $\left(K_{S S}\right)$ for undisturbed rangeland. Soil loss in undisturbed rangeland is dominated by splash 
and sheet erosion in which bare patches between plant canopies are sources for runoff generation and soil detachment by rain splash. In these situations, patches of ground cover intercept and store rainfall and overland flow and facilitate infiltration and sediment retention (Pierson et al., 1994; Davenport et al., 1998; Wilcox et al., 2003; Puigdefábregas, 2005), which reduces the chance of overland flow becoming concentrated (Al-Hamdan et al., 2012b, 2013). However, the same landscapes with a broad-scale disturbance that results in loss of understory plants and ground cover often experience significantly more runoff and soil loss from a similar runoff event due to increased connectivity of bare soils and formation of well-organized concentrated flow paths (Williams et al., 2016). These accentuated flow paths rapidly accelerate runoff velocity and the ability of water to erode and transport sediment downslope (Wilcox et al., 1996; Pierson et al., 2008, 2009; Urgeghe et al., 2010; Pierson et al., 2013; Williams et al., 2014, 2016).

Al-Hamdan et al. (2012a) used data from overland flow simulation plots ( $2 \mathrm{~m}$ wide and $4 \mathrm{~m}$ long) to develop equations that estimate concentrated flow erodibility $\left(K_{\omega}\right)$ for RHEM using readily measureable soil and vegetation data. Using these $K_{\omega}$ estimate equations, Al-Hamdan et al. (2015) tested RHEM applications on disturbed rangelands and found that the model was able to predict erosion on disturbed rangeland within a satisfactory range of error if measured splash and sheet erodibility $\left(K_{S S}\right)$ was used. However, the model did not perform very well when using the $K_{S S}$ estimation equations that were developed for undisturbed rangelands. Therefore, new $K_{S S}$ estimation equations are needed for parameterizing $K_{S S}$ for RHEM application on disturbed rangeland.

The goal of this study is to develop a new broadly applicable parameterization approach to estimate erodibility on undisturbed and disturbed rangelands for RHEM. Specific objectives of this study are: (1) to develop empirical equations that predict the splash and sheet flow erodibility parameter $\left(K_{S S}\right)$ for undisturbed and disturbed rangeland using readily measureable vegetation data, and (2) to evaluate the applicability of the new empirical equations in RHEM in two cases: with the assumption of insignificant concentrated flow erodibility, and with the assumption that concentrated flow erodibility is the dominant erosion process.

\section{MeTHOdS AND MATERIALS}

In order to develop the new erodibility parametrization approach, data from different rainfall simulation field experiments were used. Two sets of data were used: one for developing the $K_{S S}$ parameterization equation, and one for the evaluation. The following sections describe each data set.

\section{DATA USED FOR DEVELOPING THE PARAMETERIZATION APPROACH}

The data used for developing the erodibility parameter equations included rainfall simulation experiment data collected for WEPP (Johnson and Blackburn, 1989; Simanton et al., 1991; Laflen et al., 1991), IRWET, and NRST (Franks et al., 1998; Pierson et al., 2002) studies. In these studies, a rotating-boom rainfall simulator (Swanson, 1965) was used to simulate rainfall for $30 \mathrm{~min}$ at about $60 \mathrm{~mm} \mathrm{~h}^{-1}$ intensity. Each plot was pre-wetted $24 \mathrm{~h}$ earlier by conducting rotating-boom rainfall simulation at the initial soil moisture for $1 \mathrm{~h}$ at about $60 \mathrm{~mm} \mathrm{~h}^{-1}$ intensity. The data include a natural treatment (undisturbed) and a bare treatment (standing vegetation was removed to the ground by clipping, and ground cover was removed by hand) (Johnson and Blackburn, 1989). Plot sizes were $10.7 \mathrm{~m}$ long and $3.05 \mathrm{~m}$ wide. Ground cover, foliar cover, and foliar life form were measured for all plots using a point-frequency frame. The vegetation community of each plot was decided based on the dominant measured life form. The combined data sets cover a wide scope of soil texture and vegetation type (table 1). Soil texture, ground surface slope, sediment rates, and runoff were measured for each plot. For each plot, the erodibility parameter $K_{S S}$ was calculated by equation 1 using the measured runoff, sediment yield, and rainfall intensity.

\section{DATA USED For Model Evaluation}

The data used to evaluate the new parameterization approach in RHEM were obtained from independent rainfall simulation experiments conducted by the USDA-ARS Northwest Watershed Research Center, Boise, Idaho (Pierson et al., 2007, 2009, 2010, 2013; Moffet et al., 2007; Williams et al., 2014). These experiments applied a Colorado State University type rainfall simulator (Holland, 1969) consisting of multiple stationary sprinklers elevated $3.05 \mathrm{~m}$ above the ground surface (Pierson et al., 2007, 2009, 2010, 2013). Data were obtained for multiple sites, including sagebrush sites that have been encroached by conifers and/or burned by prescribed fire or wildfire. Plot length in this group varied from 6 to $7 \mathrm{~m}$, and width varied from 2 to $5 \mathrm{~m}$. The rainfall intensity and duration varied among sites (table 2). Usually, plots were pre-wetted by applying rainfall simulation for a specific period of time under dry antecedent soil moisture conditions.

\section{Statistical ANALYSIS}

SAS software (SAS, 2007) was used for all statistical analyses. Multiple stepwise linear regression analysis was used to derive the relationship between erodibility as dependent variable and ground and foliar cover attributes, slope, and soil texture as independent variables. The general linear model was used to test the significance of differences between erodibility mean values among vegetation communities. Prior to this analysis, values of erodibility were log transformed (base 10) to address deviation from normality as well as to improve homoscedasticity and linearity (Allison, 1999).

Residual plots were used to examine the homoscedasticity and linearity assumptions. Piecewise (segmented) regression analysis was applied in which two continuous relationships between the log-transformed erodibility and the independent variables were fitted to improve the linear relationship (Ryan et al., 2002, 2005). The PROC NLIN analysis technique in SAS was used to find the breakpoint at which the relationship between erodibility and ground cover changed (Ryan and Porth, 2007). A significance level of 0.05 
Table 1. Experimental sites used to develop the erodibility parameterization schemes.

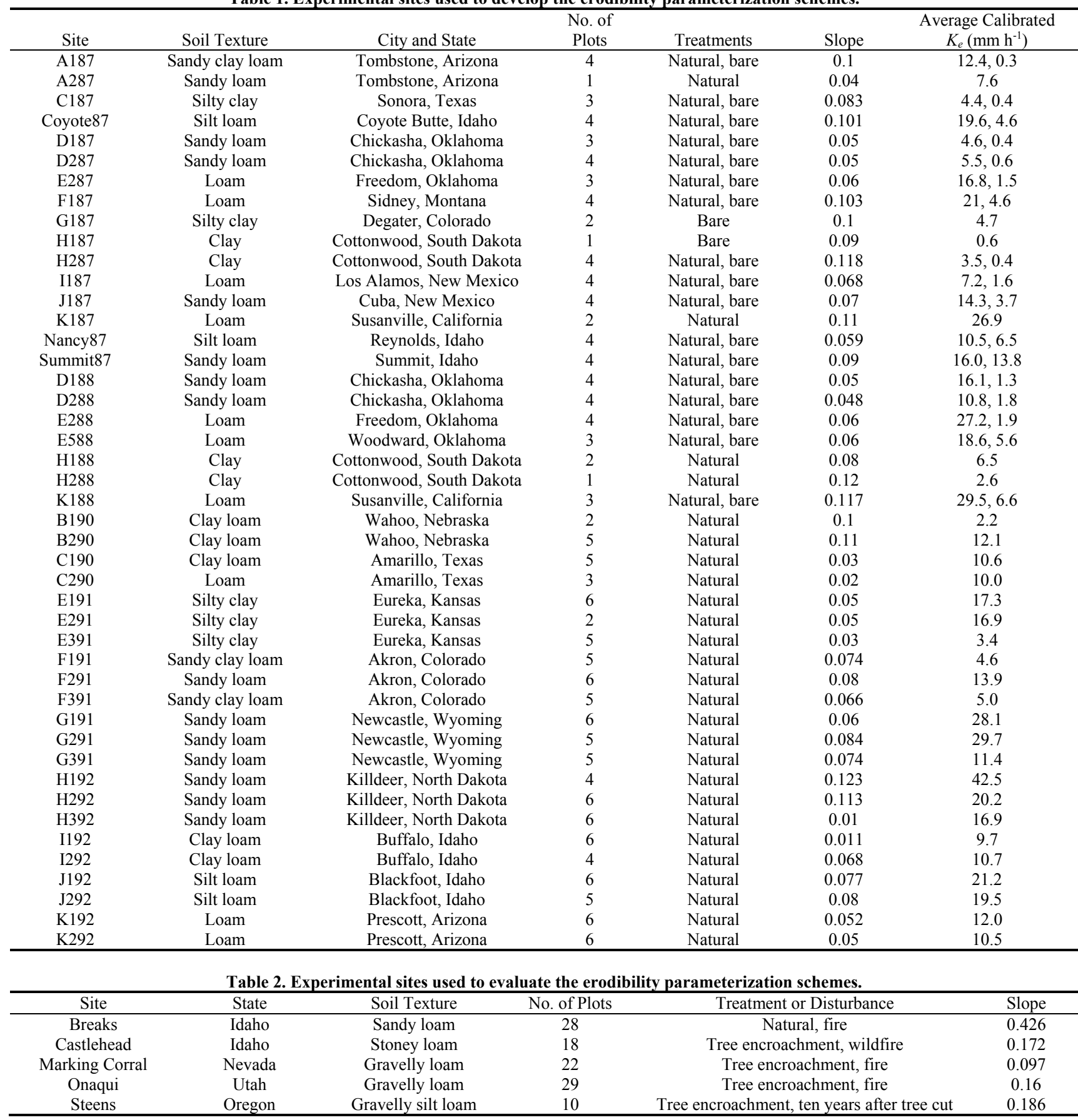

was used for all statistical tests, including the criteria for including the variables in the multiple regressions. Percent bias (PBIAS; Gupta et al., 1999) was used to evaluate the applicability of the new parameterization scheme in RHEM:

$$
\text { PBIAS }=\frac{\sum_{i=1}^{n}\left(O_{i}-M_{i}\right)}{\sum_{i=1}^{n}\left(O_{i}\right)} \times 100
$$

where

$O_{i}=i$ th observation to be evaluated

$M_{i}=$ simulated value by the model for the corresponding $i$ th observation

$n=$ number of observations.
Performance of the sediment prediction is considered "very good" when PBIAS $< \pm 15$, "good" when $\pm 15 \leq$ PBIAS $< \pm 30$, "satisfactory" when $\pm 30 \leq$ PBIAS $< \pm 55$, and "unsatisfactory" when PBIAS $\geq \pm 55$ (Moriasi et al., 2007).

\section{RHEM SIMULATIONS FOR EVALUATING THE ERODIBILITY PARAMETERIZATION APPROACH}

To test the performance of the new erodibility parameterization schemes, the hydraulic conductivity $\left(K_{e}\right)$ was optimized on the total volume of runoff for each plot. By using optimized $K_{e}$ values (table 1), average total runoff converged within less than a $0.01 \mathrm{~mm}$ of the average measured values for all plots. The erosion model performance was analyzed 
in two different parameterization schemes for erodibility.

In the first parameterization scheme (scheme 1), the model performance was tested using splash and sheet erodibility $\left(K_{S S}\right)$ parameters estimated by the new empirical equations developed in this study, while concentrated flow erodibility $\left(K_{\omega}\right)$ was set as the default value in the current RHEM version $\left(7.747 \times 10^{-6} \mathrm{~s}^{2} \mathrm{~m}^{-2}\right)$. This small value of concentrated flow erodibility is typical for undisturbed rangeland. In this scheme, it was assumed that sediment detachment is dominated by rain splash and thin sheet flow, while the major role of concentrated flow paths is transporting the splashsheet detached sediments.

In the second parameterization scheme (scheme 2), $K_{S S}$ was estimated in the same way as in scheme 1 in all plots. However, $K_{\omega}$ was different for plots where it was assumed that concentrated flow detachment was significantly high. These plots had two major characteristics: they had been abruptly disturbed and their overland flow was most likely to concentrate because of slope steepness (i.e., slope $>0.2$; AlHamdan et al., 2013). The concentrated flow detachment capacity for these plots was calculated as:

$$
\left.D_{c}=P\left(K_{\omega(\max }\right)^{\beta q_{c}}\right)(\omega)+(1-P) K_{\omega}(\omega)
$$

where

$P=$ probability of overland flow to concentrate

$K_{\omega(\max )}=$ user-calculated maximum concentrated flow erodibility $\left(\mathrm{s}^{2} \mathrm{~m}^{-2}\right)$ at the time of runoff initiation (see eq. 6)

$\beta=$ erodibility decay factor $\left(-5.53 \mathrm{~m}^{-2}\right)$

$q_{c}=$ cumulative unit flow discharge $\left(\mathrm{m}^{2}\right)$

$\omega=$ stream power $\left(\mathrm{kg} \mathrm{s}^{-3}\right)$.

$K_{\omega}$ was also assumed as the default value in RHEM $\left(7.747 \times 10^{-6} \mathrm{~s}^{2} \mathrm{~m}^{-2}\right)$. This means that if $P=0$, then scheme 2 becomes similar to scheme 1 .

The probability of overland flow to concentrate $(P)$ was calculated with the following equation (Al-Hamdan et al., 2013):

$$
P=\frac{\exp (-6.397+8.335 S+3.252 \text { bare }+3440 q)}{1+\exp (-6.397+8.335 S+3.252 \text { bare }+3440 q)}
$$

where

$S=$ slope gradient (expressed as a fraction)

bare $=$ fraction of bare ground

$q=$ flow discharge per unit width $\left(\mathrm{m}^{2} \mathrm{~s}^{-1}\right)$.

The variables $q_{c}$ and $\omega$ are derived internally by the model and applied by RHEM as described by Al-Hamdan et al. (2012a, 2013, 2015). Concentrated flow paths in RHEM are spaced in $1 \mathrm{~m}$ increments perpendicular to the hillslope angle. This means that concentrated flow paths are always formed, and the distance between each flow path is $1 \mathrm{~m}$. Therefore, the interpretation of $P$ becomes the probability that overland flow will be a significantly highly erosive concentrated flow. For a highly eroding concentrated flow scheme, $K_{\omega(\max )}$ was calculated with the following equation from Al-Hamdan et al. (2012a):

$$
\begin{aligned}
\log _{10} K_{\omega(\max )} & =-3.46-1.97(\text { res }+ \text { bascry }) \\
& -1.85 \text { rock }-4.99 \text { clay }+6.06 \text { silt }
\end{aligned}
$$

where res, bascry, rock, clay, and silt are, respectively, the area fraction of surface litter, sum of basal and cryptogam covers, surface rock cover, and surface soil clay and silt content fractions. Ground cover or bare ground fractions, such as those used in equations 5 and 6 , can be estimated using a linepoint intercept procedure (Herrick et al., 2005). For instance, in the data used to develop these two equations, ground cover presence and type were recorded for 24 points with $20 \mathrm{~cm}$ spacing along each of nine evenly spaced (20 cm apart, perpendicular to hillslope contours) transects $4.6 \mathrm{~m}$ in length (216 points in total). The area fraction of cover type was calculated by dividing the number of points with a particular ground cover by the total number of the points.

\section{RESULTS AND DiscUSSION \\ RANGES OF EROSIVITY, ERODIBILITY, AND SEDIMENT TRANSPORT PARAMETERS}

The runoff rates in the data used for developing the erodibility equations varied from $1.4 \times 10^{-8}$ to $1531 \times 10^{-8} \mathrm{~m} \mathrm{~s}^{-1}$ $\left(0.05\right.$ to $\left.55.1 \mathrm{~mm} \mathrm{~h}^{-1}\right)$. Total generated runoff depths for each rainfall simulation varied from 0.05 to $31.2 \mathrm{~mm}$. Rainfall intensity varied from 44.9 to $70.3 \mathrm{~mm} \mathrm{~h}^{-1}$. Stream power values varied from $0.2 \times 10^{-3}$ to $158.3 \times 10^{-3} \mathrm{~kg} \mathrm{~s}^{-3}$. The transport capacity per unit width varied from $2 \times 10^{-6}$ to $52,200 \times 10^{-6}$ $\mathrm{kg} \mathrm{s}^{-1} \mathrm{~m}^{-1}$. The values of measured sediment transport rate to transport capacity ratio were low, with an average of $12 \%$, which indicated that in general the erosion process in the experiments was not limited by transport capacity. The values of probability of overland flow to concentrate varied from 0.002 to 0.112 , with an average value of 0.021 , which indicated that the dominant soil detachment processes are rain splash and sheet flow erosion.

\section{SPLASH AND SHEET ERODIBILITY ESTIMATION EQUATIONS}

Splash-sheet erodibility was negatively correlated with ground cover and canopy cover and was positively correlated with slope. The regression analysis to develop equations that describe the relationship between $K_{S S}$ as dependent variable and ground cover, foliar cover, slope, and soil texture resulted in the following equations:

$$
\begin{gathered}
\log _{10} K_{S S}=4.075-1.767 G \\
\left(n=181, \mathrm{R}^{2}=0.57\right) \\
\log _{10} K_{S S}=4.051-1.241 G-0.883 F \\
\left(n=181, \mathrm{R}^{2}=0.65\right) \\
\log _{10} K_{S S}=3.753-1.248 G-0.96 F+4.399 S \\
\left(n=181, \mathrm{R}^{2}=0.68\right)
\end{gathered}
$$

where $G$ is the area fraction of ground cover, and $F$ is the area fraction of foliar cover. Although adding slope to the regression only increases $R^{2}$ by 0.03 , the regression analysis for equation 9 shows that $K_{S S}$ is dependent on slope $(\mathrm{p}<$ 
0.0001). As Al-Hamdan et al. (2015) suggested, in rangeland sites that exhibit some kind of disturbance, sites with the same vegetation cover, but a significant difference in slope angle, can have very different splash and sheet erodibility values. Increasing slope steepness decreases the effect of soil particle weight on detachment resistance, which leads to larger erodibility (Moody et al., 2005). This phenomenon might be more important for exposed loose soil where soil particle weight is the dominant source of detachment resistance. Sediment availability is high immediately following disturbance (Al-Hamdan et al., 2015; Nyman et al., 2013) and declines over time due to repeated winnowing. This gradual reduction in exposed loose sediment availability may reduce the dependency of erodibility on the slope factor.

The regression analysis shows that $K_{S S}$ was not dependent on soil texture. This could be because cover is the first and major factor affecting erodibility, where it acts like a protection shield for soil particles from raindrops. Soil texture may exert a greater influence on erodibility when the ground surface is bare and exposed to raindrop impact. At this point, soil texture will be an important factor for overland flow erodibility, such as in equation 6 .

The residual of the regression analysis of equation 9 (fig. 1a) shows that even though $\log$ transformation improved the homoscedasticity and linearity, these assumptions were not totally satisfied since the equation is still underestimating high erodibility values at low ground cover. In order to address this problem, piecewise regression analysis was applied to develop two continuous linear relationships that intersect at a breakpoint. The piecewise regression analysis showed that the best two-piece regression occurs when a ground cover value of 0.475 is the break point:

$$
\begin{aligned}
& \log _{10} K_{S S}= \\
& \left\{\begin{array}{c}
4.1229-2.4334 G-0.829 F+3.104 S \\
\text { if } G \leq 0.475 \\
3.2289975-0.5515 G-0.829 F+3.104 S \\
\text { if } G>0.475
\end{array}\right.
\end{aligned}
$$

The coefficient of determination in the piecewise regression analysis was greater $\left(\mathrm{R}^{2}=0.708\right)$ than in the analysis resulting in equation 9. Homoscedasticity was also improved by applying the piecewise regression approach, as the model's ability to predict $K_{S S}$ (i.e., range of residual values) at low and high ground cover becomes more similar (fig. 1b). The breakpoint generated by the piecewise regression identifies a threshold at which there is a substantial change in the rate of erodibility increase with respect to bare soil area and therefore provides an objective means for detecting changes between natural and disturbance phases. The value of 0.475 corroborates with several studies which concluded that the erosion to runoff ratio (erodibility) increases substantially when bare ground exceeds $50 \%$ (e.g., Al-Hamdan et al., 2013; Pierson et al., 2013). This is supported by extensive reviews of the literature on rangeland cover by Gifford (1985) and Weltz et al. (1998), which concluded that ground cover should be maintained above a critical threshold of $50 \%$ to $60 \%$ to adequately protect the soil surface. The general linear model analysis showed that the mean value of erodibility is significantly different in at least one of the vegetation communities. Applying the general linear regression analysis along with the piecewise approach for four different vegetation communities resulted into the following equations:

Bunch grass:

$$
\begin{aligned}
& \log _{10} K_{S S}= \\
& \left\{\begin{array}{c}
4.154-2.547 G-0.7822 F+2.5535 S \\
\text { if } G \leq 0.475 \\
3.1726975-0.4811 G-0.7822 F+2.5535 S \\
\text { if } G>0.475
\end{array}\right.
\end{aligned}
$$

Sod grass:

$$
\begin{aligned}
& \log _{10} K_{S S}= \\
& \left\{\begin{array}{c}
4.2169-2.547 G-0.7822 F+2.5535 S \\
\text { if } G \leq 0.475 \\
3.2355975-0.4811 G-0.7822 F+2.5535 S \\
\text { if } G>0.475
\end{array}\right.
\end{aligned}
$$

Shrub:

$$
\begin{aligned}
& \log _{10} K_{S S}= \\
& \left\{\begin{array}{c}
4.2587-2.547 G-0.7822 F+2.5535 S \\
\text { if } G \leq 0.475 \\
3.2773975-0.4811 G-0.7822 F+2.5535 S \\
\text { if } G>0.475
\end{array}\right.
\end{aligned}
$$

Forbs:

$$
\begin{aligned}
& \log _{10} K_{S S}= \\
& \left\{\begin{array}{c}
4.1106-2.547 G-0.7822 F+2.5535 S \\
\text { if } G \leq 0.475 \\
3.1292975-0.4811 G-0.7822 F+2.5535 S \\
\text { if } G>0.475
\end{array}\right.
\end{aligned}
$$

Dividing the data into four groups based on the dominant vegetation community by applying the general linear model improved the coefficient of determination with a slight increase $\left(\mathrm{R}^{2}=0.713\right)$ compared to equation 10 . Using equations 11 through 14 in lieu of equation 10 did not change the performance of the prediction significantly. However, it can be seen that the variable coefficient values in equation 10 are different from those in equations 11 through 14. For instance, the ground cover coefficients changed from 2.4334 and 0.5515 in equation 10 to 2.547 and 0.4811 , respectively, in equations 11 through 14, which could change the resulting $K_{S S}$ values (fig. 2). In addition, using different equations for different vegetation communities might be necessary when comparing hydrologic and erosion responses for different undisturbed ecological sites. At these sites, the slight difference in the log scale could indicate a high percentage of difference between two sites with low erosion values. 

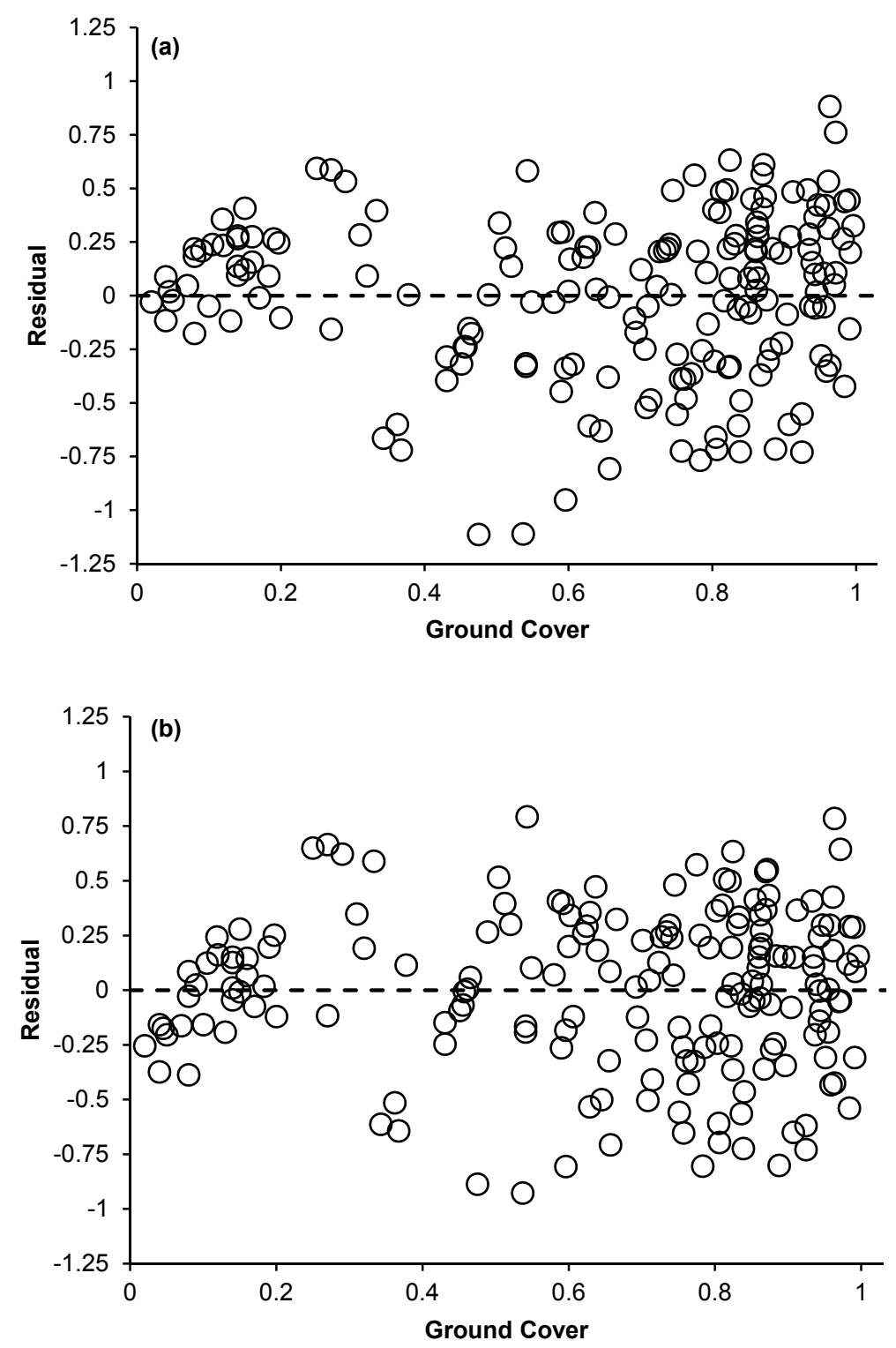

Figure 1. Ground cover versus regression analysis residual associated with (a) equation 9 and (b) equation 10.

\section{ERodibility Parameterization Evaluations}

Figure 3a shows the measured $\log _{10} K_{S S}$ values for each plot from the evaluation data set versus the estimated $\log _{10} K_{S S}$ using equation 13 . The shrub equation was used to estimate $K_{S S}$ for this evaluation since the evaluation data set is dominantly shrubland or tree-encroached shrubland. It can be seen that equation 13 performed within a reasonable margin of error (PBIAS $=3.26$ ) given that the data set used for the evaluation had a different experimental design. Another source of error could be that the assumption of splash and sheet sediment detachment dominance was not satisfied in some of the evaluation plots, especially in steeply sloped, highly disturbed sites. Under these conditions, plots with extensive bare soil would exhibit a greater likelihood for overland flow concentration (Al-Hamdan et al., 2013). For instance, the average value of the probability, calculated by equation 5 , of overland flow to concentrate into incised flow paths in this data set varied from 0.006 to 0.579 , with an av- erage value of 0.112 . Moreover, these concentrated flow paths, especially on sites that exhibit some kind of abrupt disturbance, are most likely filled with loose sediments. Therefore, in these plots, taking concentrated flow erodibility $\left(K_{\omega}\right)$ into account is merited.

Estimating $K_{S S}$ by weighted averaging between equations 11 through 14 based on the percentage of life form presented reduced the values of $K_{S S}$ (fig. $3 \mathrm{~b}$ ). Because the shrub equation generated the highest erodibility values, weighing in the other equations reduced the estimated erodibility. However, the margin of error was still reasonable (PBIAS = $4.5)$.

\section{RHEM SIMULATIONS}

The results when applying parameterization scheme 1 show that the overall performance of RHEM using the estimated $K_{S S}$ had a satisfactory PBIAS value of 41.8 (fig. $4 \mathrm{a}$ ). In general, model simulations overestimated low sediment 


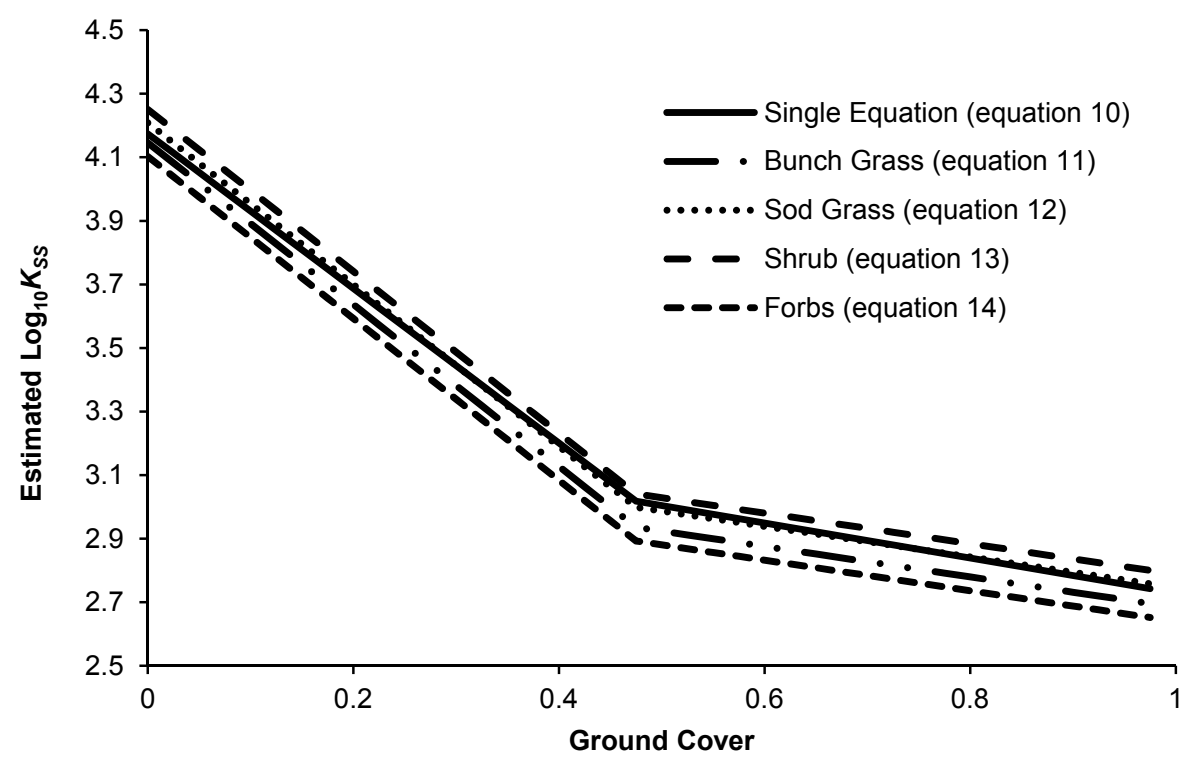

Figure 2. Values of $\log _{10} K_{S S}$ using equations 10 through 14 versus ground cover when slope is 0.15 and foliar is 0.5 .

yield values and underestimated high sediment yield values. The bias at the two ends of the erosion rates is typical for all erosion models because of the limitations in representing the random components in measured data within replicates (Nearing, 1998). However, the simulations were still able to match more than $50 \%$ of the measured sediment yield at highly disturbed sites. The margin of error is considered reasonable, given that the data set used for developing the parameterization scheme and the data set used for the evaluation were obtained using different rainfall simulators. The model was also evaluated when using $K_{S S}$ estimated by weighted averaging between equations 11 through 14 based on the percentage of life form present in each plot. The results show that model performance was still satisfactory, with a PBIAS value of 54.9 (fig. $4 \mathrm{~b}$ ).

Two possible sources of error drive the model bias. The first source of error is the range of error in the measured values of sediment yield and total runoff. The second source of error is in the hydrology component. Erosion is highly dependent on runoff (Pierson et al., 2010, 2013; Williams et al., 2014), and decreased accuracy in predicting runoff decreases the accuracy of erosion predictions. Even though the model was optimized for total runoff, runoff starting time and the shape of the hydrograph (e.g., peak time, rising limb, and recession limb) were not always matched with the experimental values. Given the cumulative uncertainty associated with measured data in rainfall simulation and soil erosion experiments, the model still performed with a reasonable margin of error.

Caution should be taken against using the procedure with data that fall outside the range of slopes from which the regression equations were developed (table 3 ). For example, figure 5 shows the boundaries of ranges of $K_{S S}$ values from the shrub equation when slope equals 0.1 and when foliar equals 0.05 . It can be seen that use of the equation at high slope values may overestimate the $K_{S S}$ values in well covered sites, as one would expect that the $K_{S S}$ values would not be sensitive to slope at these sites. However, $K_{S S}$ values at low cover would be sensitive to slope, which means that applying the equations on such sites would be acceptable. An example of steep slope with high cover and low cover cases can be seen in the Breaks site, where the model performed very well at lower cover (after fire) but overestimated $K_{S S}$ in the well protected area before fire.

Applying parameterization scheme 2 improved the overall performance of the model, with a lower absolute value of PBIAS (fig. 4c). However, the model still predicted about $50 \%$ of the measured sediment yield for highly erodible areas, which means that adding equation 4 for these sites did not change the prediction significantly.

\section{RECOMMENDED APPLICATIONS IN RHEM}

The performance of the model with the new parameterization schemes indicated that using $K_{S S}$ alone as the indicator of erodibility in RHEM works reasonably well as long as concentrated flow paths function only for transport of the splash and sheet-sourced sediments, as opposed to functioning also as significant sediment sources. In order for concentrated flow paths on rangelands to generate sediment detachment, they need to have high erodibility values (i.e., high availability of erodible sediment) and high erosivity (i.e., stream power that increases with slope steepness). An abrupt disturbance that exposes loose sediments on a gentle slope, such as the bare treatment plots in this study, would increase the erodibility. However, the stream power may be too small to cause significant soil detachment, and the transport capacity would be used for moving the splash and sheet loose sediments. Gradually disturbed sites, such as the tree-encroached plots in this study, have minimum loose sediments in the concentrated flow paths, as they have been eroding at reasonably high rates for years. Therefore, the only case in which concentrated flow erodibility is not negligible is when an abrupt disturbance exposes loose sediments on a steep slope. At these sites, the $P$ value in equation 5 would be too large to assume zero. 

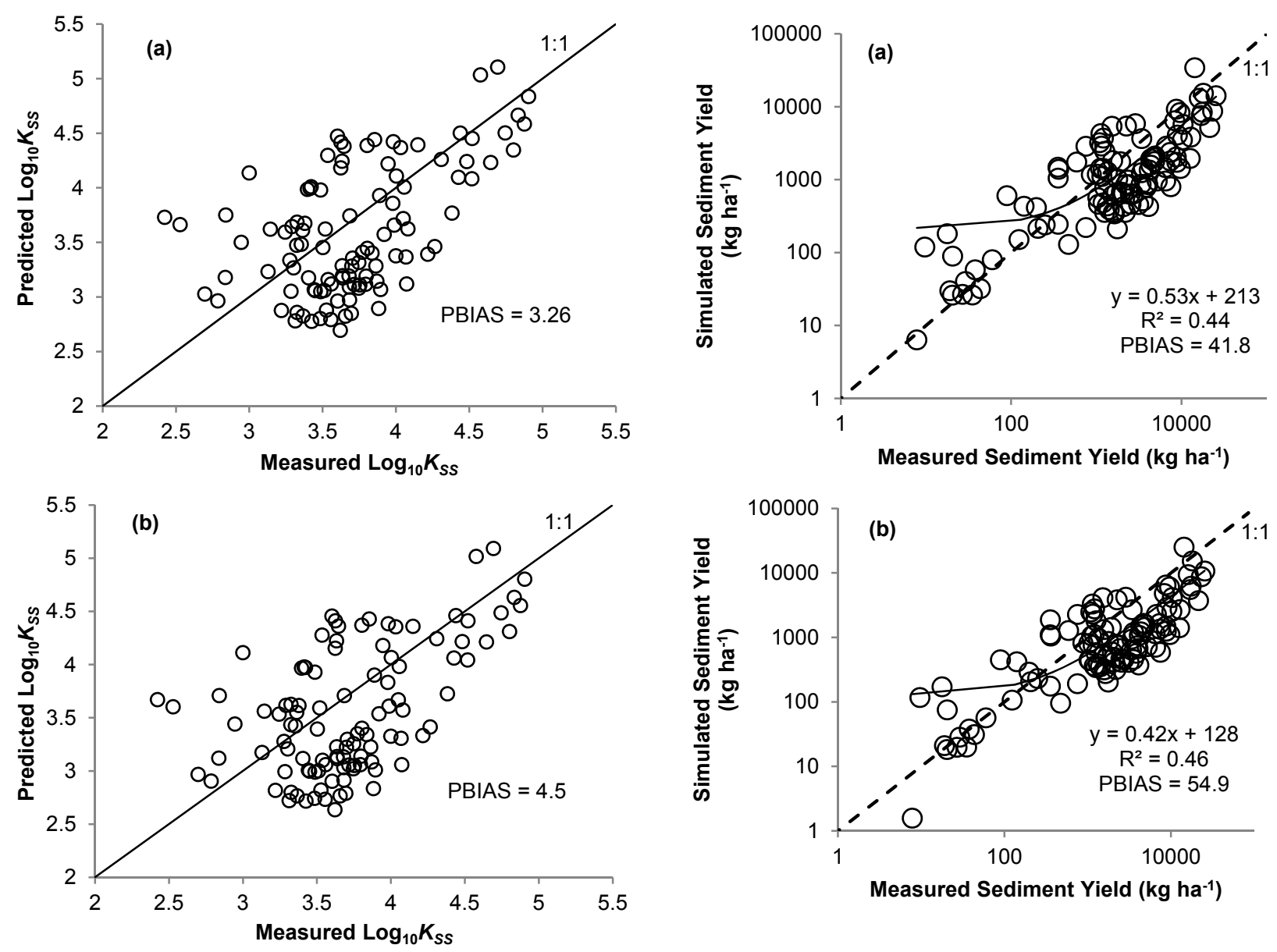

Figure 3. Values of $\log _{10} K_{s s}$ calibrated on measured sediment yield versus estimated $\log _{10} K_{s s}$ using (a) equation 13 and (b) weighted averaging between equations 11 through 14 based on the percentage of life form.

Either equation 10 or equations 11 through 14 can be used to estimate $K_{S S}$ without significant performance difference. However, equation 10 provides a less complex approach. Plant life forms (grass, forbs, shrubs) and growth habit (sodgrass, bunchgrass) exhibit significant effects on factors that determine surface hydrology, such as $K_{e}$ (Spaeth et al., 1996; Pierson et al., 2002). Because the hydraulic conductivity $\left(K_{e}\right)$ in this study was optimized on total volume of runoff, further investigation is needed to check the impact of incorporating equations 11 through 14 when surface hydrology is also modeled.

\section{SUMMARY AND CONCLUSIONS}

In this study, new parameterization schemes for erodibility were developed for the application of RHEM on undisturbed and disturbed rangelands. In most cases, only one erodibility parameter $\left(K_{S S}\right)$ is needed to run the model, minimizing the error that can be generated from the parameterization process. Empirical equations were developed that predict $K_{S S}$ in terms of readily available parameters of ground cover, vegetation cover, and slope. Both erodibility parameters $\left(K_{\omega}\right.$ and $\left.K_{S S}\right)$ might be needed only in the special case of abrupt disturbance with steep slopes and high silt. Evalua-

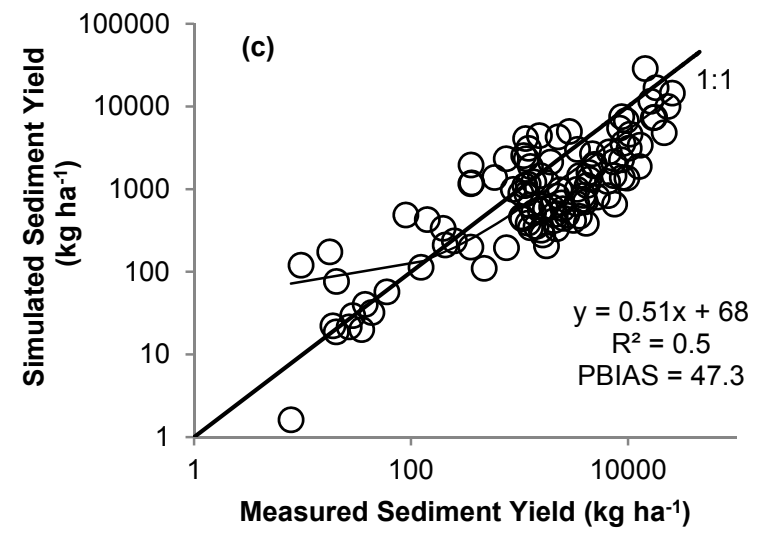

Figure 4. Measured sediment yield versus sediment yield estimated by RHEM when (a) using equation 13 for estimating $K_{S S}$ while assuming no significant eroding concentrated flow, (b) using weighted averaging between equations 11 through 14 based on the percentage of life form to estimate $K_{S S}$ while assuming no significant eroding concentrated flow, and (c) using weighted averaging between equations 11 through 14 based on the percentage of life form to estimate $K_{S S}$ while concentrated flow detachment rate was calculated using equation 4.

tion of RHEM with the new parameterization schemes indicated the ability of the model to predict erosion at the plot scale within a satisfactory range of error. The new parameterization approach expands the applicability of RHEM to a greater scope of landscapes and soil textures. 
Table 3. Ranges of variables used to develop $K_{S S}$ estimation equations.

\begin{tabular}{cccc}
\hline Variable & Mean & Minimum & Maximum \\
\hline Foliar cover & 0.358473 & 0 & 0.908163 \\
Ground cover & 0.648806 & 0.02 & 0.995918 \\
Rock cover $^{[a]}$ & 0.016224 & 0 & 0.26 \\
Vegetation cover $^{[a]}$ & 0.606251 & 0 & 0.995918 \\
Slope & 0.075116 & 0.02 & 0.13 \\
$D_{S S}$ & $2.92 \mathrm{E}-05$ & $1.67 \mathrm{E}-08$ & 0.000378 \\
$I\left(\mathrm{~m} \mathrm{~s}^{-1}\right)$ & $1.6 \mathrm{E}-05$ & $1.25 \mathrm{E}-05$ & $1.95 \mathrm{E}-05$ \\
$q\left(\mathrm{~m}^{2} \mathrm{~s}^{-1}\right)$ & $4.78 \mathrm{E}-06$ & $1.39 \mathrm{E}-08$ & $1.53 \mathrm{E}-05$ \\
$K_{S S}[\mathrm{~b}]$ & 3063.82 & 34.70589 & 29838.19 \\
$K_{e}^{[\mathrm{c}]}$ & 12.7 & $\sim 0$ & 46 \\
\hline
\end{tabular}

[a] After dropping two outlier points with high rock value.

[b] Calibrated on measured $D_{S S}$.

[c] Calibrated on total runoff $\left(\mathrm{mm} \mathrm{h}^{-1}\right)$.
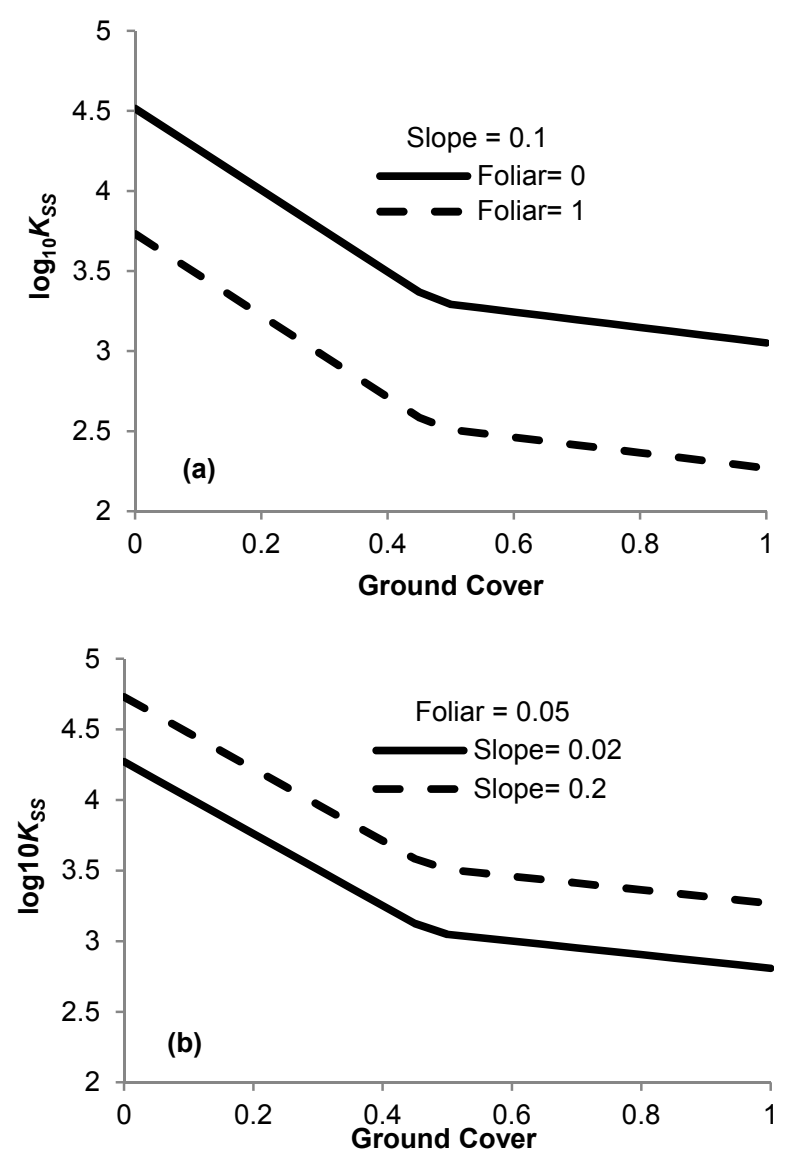

Figure 5. Boundaries of ranges of values of $\log _{10} K_{S S}$ estimated by equation 13 at (a) fixed slope value of 0.1 with foliar ranges from 0 to 1 and (b) fixed foliar of 0.05 with slope ranges from 0.02 to 0.2 .

The new approach for estimating $K_{S S}$ for RHEM has several advantages. First, the results of this study indicate that, in most cases, the model will be dependent on only one erodibility parameter. Second, the approach addresses the phenomenon that erosion rates become larger at a specific threshold point. Third, the equations use readily available data for estimating erodibility values. Fourth, the approach covers continuously a wide range of ground cover and foliar cover. For future work, adding more data that represent unique cases, such as sites with saline and sodic soils and sites dominantly covered with biological soil crusts, would expand the applicability of the equations.

\section{ACKNOWLEDGEMENTS}

This research was funded in part by the USDANRCS/ARS Conservation Effects Assessment Project (CEAP) and the U.S. Joint Fire Sciences program. This is Contribution No. 114 of the Sagebrush Steppe Treatment Evaluation Project (SageSTEP), funded by the U.S. Joint Fire Science Program.

\section{REFERENCES}

Al-Hamdan, O. Z., Hernandez, M., Pierson, F. B., Nearing, M. A., Williams, C. J., Stone, J. J., ... Weltz, M. A. (2015). Rangeland hydrology and erosion model (RHEM) enhancements for applications on disturbed rangelands. Hydrol. Proc., 29(3), 445457. http://dx.doi.org/10.1002/hyp.10167

Al-Hamdan, O. Z., Pierson, F. B., Nearing, M. A., Stone, J. J., Williams, C. J., Moffet, C. A., ... Weltz, M. A. (2012b). Characteristics of concentrated flow hydraulics for rangeland ecosystems: implications for hydrologic modeling. Earth Surf. Proc. Landforms, 37(2), 157-168. http://dx.doi.org/10.1002/esp.2227

Al-Hamdan, O. Z., Pierson, F. B., Nearing, M. A., Williams, C. J., Stone, J. J., Kormos, P. R., ... Weltz, M. A. (2012a). Concentrated flow erodibility for physically based erosion models: Temporal variability in disturbed and undisturbed rangelands. Water Resour. Res., 48(7), W07504. http://dx.doi.org/10.1029/2011WR011464

Al-Hamdan, O. Z., Pierson, F. B., Nearing, M. A., Williams, C. J., Stone, J. J., Kormos, P. R., ... Weltz, M. A. (2013). Risk assessment of erosion from concentrated flow on rangelands using overland flow distribution and shear stress partitioning. Trans. ASABE, 56(2), 539-548. http://dx.doi.org/10.13031/2013.42684

Allison, P. D. (1999). Multiple regression: A primer. Oaks, CA: Pine Forge Press.

Davenport, D. D., Breshears, D. D., Wilcox, B. P., \& Allen, C. D. (1998). Viewpoint: Sustainability of piñon-juniper ecosystems: A unifying perspective of soil erosion thresholds. J. Range Mgmt., 51(2), 231-240. http://dx.doi.org/10.2307/4003212

Franks, C. D., Pierson, F. B., Mendenhall, A. G., Spaeth, K. E., \& Weltz, M. A. (1998). Interagency rangeland water erosion project report and state data summaries. NWRC 98-1. Boise, ID: USDA-ARS Northwest Watershed Research Center.

Gifford, G. F. (1985). Cover allocation in rangeland watershed management: A review. In Proc. ASCE Symp. Watershed Management in the Eighties (pp. 23-31). Reston, VA: ASCE.

Gupta, H. V., Sorooshian, S., \& Yapo, P. O. (1999). Status of automatic calibration for hydrologic models: Comparison with multilevel expert calibration. J. Hydrol. Eng., 4(2), 135-143. http://dx.doi.org/10.1061/(ASCE)1084-0699(1999)4:2(135)

Hernandez, M., Nearing, M. A., Stone, J. J., Pierson, F. B., Wei, H., Spaeth, K. E., ... Goodrich, D. C. (2013). Application of a rangeland soil erosion model using National Resources Inventory data in southeastern Arizona. J. Soil Water Cons., 68(6), 512-525. http://dx.doi.org/10.2489/jswc.68.6.512

Herrick, J. E., Van Zee, J. W., Havstad, K. M., Burkett, L. M., \& Whitford, W. G. (2005). Monitoring manual for grassland, shrubland, and savanna ecosystems: Vol. I. Quick start. Tucson, AZ: University of Arizona Press.

Johnson, C. W., \& Blackburn, W. H. (1989). Factors contributing to sagebrush rangeland soil loss. Trans. ASAE, 32(1), 156-160. http://dx.doi.org/10.13031/2013.30975

Laflen, J. M., Elliot, W. J., Simanton, J. R., Holzhey, C. S., \& Kohl, K. D. (1991). WEPP: Soil erodibility experiments for rangeland and cropland soils. J. Soil Water Cons., 46(1), 39-44. 
Moffet, C. A., Pierson, F. B., Robichaud, P. R., Spaeth, K. E., \& Hardegree, S. P. (2007). Modeling soil erosion on steep sagebrush rangeland before and after prescribed fire. Catena, 71(2), 218-228. http://dx.doi.org/10.1016/j.catena.2007.03.008

Moody, J. A., Smith, J. D., \& Ragan, B. W. (2005). Critical shear stress for erosion of cohesive soils subjected to temperatures typical of wildfires. J. Geophys. Res., 110(F1), 1-13. http://dx.doi.org/10.1029/2004JF000141

Moriasi, D. N., Arnold, J. G., Van Liew, M. W., Bingner, R. L., Harmel, R. D., \& Veith, T. L. (2007). Model evaluation guidelines for systematic quantification of accuracy in watershed simulations. Trans. ASABE, 50(3), 885-900.

Nearing, M. A. (1998). Why soil erosion models overpredict small soil losses and underpredict large soil losses. Catena, 32(1), 15 22. http://dx.doi.org/10.1016/S0341-8162(97)00052-0

Nearing, M. A., Wei, H., Stone, J. J., Pierson, F. B., Spaeth, K. E., Weltz, M. A., ... Hernandez, M. (2011). A rangeland hydrology and erosion model. Trans. ASABE, 54(3), 901-908. http://dx.doi.org/10.13031/2013.37115

Nyman, P., Sheridan, G. J., Moody, J. A., Smith, H. G., Noske, P. J., \& Lane, P. N. J. (2013). Sediment availability on burned hillslopes. J. Geophys. Res. Earth Surf., 118, 2451-2467, http://dx.doi.org/10.1002/jgrf.20152.

Pierson, F. B., Bates, J. D., Svejcar, T. J., \& Hardegree, S. P. (2007). Runoff and erosion after cutting western juniper. Rangeland Ecol. Mgmt., 60(3), 285-292. http://dx.doi.org/10.2111/15515028(2007)60[285:RAEACW]2.0.CO;2

Pierson, F. B., Moffet, C. A., Williams, C. J., Hardegree, S. P., \& Clark, P. E. (2009). Prescribed-fire effects on rill and interrill runoff and erosion in a mountainous sagebrush landscape. Earth Surf. Proc. Landforms, 34(2), 193-203. http://dx.doi.org/10.1002/esp.1703

Pierson, F. B., Robichaud, P. R., Moffet, C. A., Spaeth, K. E., Hardegree, S. P., Clark, P. E., \& Williams, C. J. (2008). Fire effects on rangeland hydrology and erosion in a steep sagebrushdominated landscape. Hydrol. Proc., 22(16), 2916-2929. http://dx.doi.org/10.1002/hyp.6904

Pierson, F. B., Spaeth, K. E., Weltz, M. A., \& Carlson, D. H. (2002). Hydrologic response of diverse western rangelands. $J$. Range Mgmt., 55(6), 558-570. http://dx.doi.org/10.2307/4003999

Pierson, F. B., Van Vector, S. S., Blackburn, W. H., \& Wood, J. C. (1994). Incorporating small-scale spatial variability into predictions of hydrologic response on sagebrush rangelands. In W. H. Blackburn, F. B. Pierson, G. E. Schuman, and R. Zartman (Eds.), Variability in rangeland water erosion processes (pp. 2334). SSSA Special Publication 38. Madison, WI: SSSA.

Pierson, F. B., Williams, C. J., Hardegree, S. P., Clark, P. E., Kormos, P. R., \& Al-Hamdan, O. Z. (2013). Hydrologic and erosion responses of sagebrush steppe following juniper encroachment, wildfire, and tree cutting. Rangeland Ecol. Mgmt., 66(3), 274-289. http://dx.doi.org/10.2111/REM-D-1200104.1

Pierson, F. B., Williams, C. J., Kormos, P. R., Hardegree, S. P., Clark, P. E., \& Rau, B. M. (2010). Hydrologic vulnerability of sagebrush steppe following pinyon and juniper encroachment. Rangeland Ecol. Mgmt., 63(6), 614-629. http://dx.doi.org/10.2111/REM-D-09-00148.1
Puigdefábregas, J. (2005). The role of vegetation patterns in structuring runoff and sediment fluxes in drylands. Earth Surf. Proc. Landforms, 30(2), 133-147. http://dx.doi.org/10.1002/esp.1181

Ryan, S. E., \& Porth, L. S. (2007). A tutorial on the piecewise regression approach applied to bedload transport data. Gen. Tech. Rep. RMRS-GTR-189. Fort Collins, CO: USDA Forest Service, Rocky Mountain Research Station.

Ryan, S. E., Porth, L. S., \& Troendle, C. A. (2002). Defining phases of bedload transport using piecewise regression. Earth Surf. Proc. Landforms, 27(9), 971-990. http://dx.doi.org/10.1002/esp.387

Ryan, S. E., Porth, L. S., \& Troendle, C. A. (2005). Coarse sediment transport in mountain streams in Colorado and Wyoming, USA. Earth Surf. Proc. Landforms, 30(3), 269-288. http://dx.doi.org/10.1002/esp.1128

SAS. (2007). SAS for Windows. Cary, N.C.: SAS Institute, Inc.

Simanton, J. R., Weltz, M. A., \& Larsen, H. D. (1991). Rangeland experiments to parameterize the Water Erosion Prediction Project model: Vegetation canopy cover effects. J. Range Mgmt., 44(3), 276-282. http://dx.doi.org/10.2307/4002957

Spaeth, K. E., Pierson, F. B., Weltz, M. A., \& Awang, J. B. (1996). Gradient analysis of infiltration and environmental variables as related to rangeland vegetation. Trans. ASAE, 39(1), 67-77. http://dx.doi.org/10.13031/2013.27481

Swanson, N. P. (1965). Rotating-boom rainfall simulator. Trans. ASAE, 8(1), 71-72. http://dx.doi.org/10.13031/2013.40430

Urgeghe, A. M., Breshears, D. D., Martens, S. N., \& Beeson, P. C. (2010). Redistribution of runoff among vegetation patch types: On ecohydrological optimality of herbaceous capture of run-on. Rangeland Ecol. Mgmt., 63(5), 497-504. http://dx.doi.org/10.2111/REM-D-09-00185.1

Wei, H., Nearing, M. A., Stone, J. J., Guertin, D. P., Spaeth, K. E., Pierson, F. B., ... Moffet, C. A. (2009). A new splash and sheet erosion equation for rangelands. SSSA J., 73(4), 1386-1392. http://dx.doi.org/10.2136/sssaj2008.0061

Weltz, M. A., Kidwell, M. R., \& Fox, H. D. (1998). Influence of abiotic and biotic factors in measuring and modeling soil erosion on rangelands: State of knowledge. J. Range Mgmt., 51(5), 482495. http://dx.doi.org/10.2307/4003363

Wilcox, B. P., Breshears, D. D. \& Allen, C. D. (2003). Ecohydrology of a resource-conserving semiarid woodland: Effects of scale and disturbance. Ecol. Monographs, 73(2), 223239.

Wilcox, B. P., Pitlick, J., Allen, C. D., \& Davenport, D. W. (1996). Runoff and erosion from a rapidly eroding pinyon-juniper hillslope. In M. G. Anderson, \& S. M. Brooks (Eds.), Advances in hillslope processes (Vol. 1, pp. 61-77). Hoboken, NJ: John Wiley and Sons.

Williams, C. J., Pierson, F. B., Al-Hamdan, O. Z., Kormos, P. R., Hardegree, S. P., \& Clark, P. E. (2014). Can wildfire serve as an ecohydrologic threshold-reversal mechanism on juniperencroached shrublands? Ecohydrology, 7(2), 453-477. http://dx.doi.org/10.1002/eco.1364

Williams, C. J., Pierson, F. B., Robichaud, P. R., Al-Hamdan, O. Z., Boll, J., \& Strand, E. K. (2016). Structural and functional connectivity as a driver of hillslope erosion following disturbance. Intl. J. Wildland Fire, 25(3), 306-321. http://dx.doi.org/10.1071/WF14114 